\title{
The $m d m-2$ Oncogene Can Overcome Wild-Type p53 Suppression of Transformed Cell Growth
}

\author{
CATHY A. FINLAY \\ Department of Molecular Biology, Princeton University, Princeton, New Jersey 08544-1014
}

Received 24 August 1992/Returned for modification 17 September 1992/Accepted 14 October 1992

\begin{abstract}
Expression of a p53-associated protein, Mdm-2 (murine double minute-2), can inhibit p53-mediated transactivation. In this study, overexpression of the Mdm-2 protein was found to result in the immortalization of primary rat embryo fibroblasts (REFs) and, in conjunction with an activated ras gene, in the transformation of REFs. The effect of wild-type p53 on the transforming properties of $m d m-2$ was determined by transfecting REFs with ras, $m d m-2$, and normal p53 genes. Transfection with ras plus $m d m-2$ plus wild-type p53 resulted in a 50\% reduction in the number of transformed foci (relative to the level for ras plus $m d m-2$ ); however, more than half $(9$ of 17) of the cell lines derived from these foci expressed low levels of a murine p53 protein with the characteristics of a wild-type p53. These results are in contrast to previous studies which demonstrated that even minimal levels of wild-type p53 are not tolerated in cells transformed by ras plus myc, E1A, or mutant p53. The $\mathbf{m d m - 2}$ oncogene can overcome the previously demonstrated growth-suppressive properties of p53.
\end{abstract}

Loss of the growth-suppressive activity of the cellular p53 protein is strongly correlated with the process of transformation. Mutations in p53 are the most common genetic alteration in human tumors $(18,25)$; in addition, several DNA tumor viruses (simian virus 40 [SV40], adenovirus type 5 , and human papillomavirus types 16 and 18) encode transforming proteins that bind to and presumably inactivate (through complex formation or enhanced degradation) wildtype p53 functions $(3,22,23,26,38,39,41)$. The cellular pathways involved in the regulation of p53 function also represent potential targets for alteration during the process of transformation. Recent studies have identified a p53associated cellular protein, murine double minute- 2 (Mdm2 ), as a potential regulator of p53 activity (29). The Mdm-2 protein can form oligomeric complexes with wild-type p53 $(17,29)$, and when $m d m-2$ is coexpressed with wild-type p53 in transient expression assays, the ability of p53 to transactivate a p53-responsive test gene is eliminated (29). The fact that $m d m-2$ can negatively regulate p53 suggests $m d m-2$ could function as an oncogene when overexpressed (in a manner analogous to that of mutant p53 or the SV40 large T antigen). Overexpression of $m d m-2$ increased the tumorigenic potential of immortalized NIH 3T3 cells, demonstrating that the Mdm-2 protein does possess oncogenic activity (6).

In this study, the transforming properties of $m d m-2$ were further characterized by assaying both the immortalizing and the transforming activities of $m d m-2$ in primary rat cells. Transfection of rat embryo fibroblasts (REFs) with $m d m-2$ in cis with a neo gene resulted in an enhancement in the number of drug-resistant colonies, and these colonies were established into immortalized cell lines with a reasonable frequency (30\%). Cotransfection of $m d m-2$ with an activated ras gene resulted in the transformation of REFs. To examine the effect of wild-type p53 overexpression on the oncogenic properties of $m d m-2$, REFs were transfected with $m d m-2$ plus ras plus wild-type murine p53. Although cotransfection with wild-type p53 resulted in a decrease in the number of transformed foci, analysis of 17 transformed cell lines derived from ras-plus- $m d m$-2-plus-wild-type p53 transfections showed that all expressed elevated levels of the Mdm-2 protein and that 9 expressed low levels of a murine p53 with properties characteristic of wild-type p53. None of the cell lines produced p53 with characteristics of a mutant p53 protein. These data suggest that overexpression of the cellular Mdm-2 protein may result in cellular transformation, at least in part, by overcoming the growth-regulatory properties of the $\mathrm{p} 53$ protein.

\section{MATERIALS AND METHODS}

Cell culture and assays for immortalization and transformation. All cells were maintained in Dulbecco's minimal essential medium (DMEM) supplemented with $10 \%$ fetal bovine serum (FBS) and incubated at $37^{\circ} \mathrm{C}$ in a humidified $5 \% \mathrm{CO}_{2}$ atmosphere. Primary REFs were prepared from 14to 15-day-old Fischer 344 whole rat embryos.

To assay immortalization activity, $6 \times 10^{5}$ to $9 \times 10^{5}$ cells were seeded per $10-\mathrm{cm}$-diameter dish and transfected on day 1 by the calcium phosphate method (12) with $0.5 \mu \mathrm{g}$ of a control vector containing the neo gene (CMV Bam Neo [17]) or CV001, a kind gift from D. George (2), or $1.8 \mu \mathrm{g}$ of a murine $m d m-2$ genomic clone (2A-43/CV001 [6]), also a generous gift from D. George, plus $10 \mu \mathrm{g}$ of carrier DNA. Expression of the $m d m-2$ gene was driven by its own promoter. On day 2 , the cells were rinsed and refed with fresh medium; on day 3 , the cells were trypsinized and seeded at $5 \times 10^{5}$ or $1 \times 10^{6}$ cells per 15 -cm-diameter dish into Geneticin 418 (G418; $600 \mu \mathrm{g} / \mathrm{ml}$ )-containing medium. G418-resistant colonies were cloned into medium without G418. Only clones derived from transfections with $m d m-2$ were successfully expanded into $10-\mathrm{cm}$-diameter dishes. Immortalized cell lines were passaged weekly at split ratios of $1: 10$ or $1: 20$ a minimum of five times.

The transforming properties of $m d m-2$ were assayed in cooperation with an activated ras gene. Primary REFs were seeded into $10-\mathrm{cm}$-diameter dishes at a density of $3 \times 10^{5}$ to $5 \times 10^{5}$ cells and were transfected on day 1 by the calcium phosphate method (12) with $1.25 \mu \mathrm{g}$ of an activated ras gene (T24 [11]) plus $4.5 \mu \mathrm{g}$ of a genomic $m d m-2$ clone $(2 \mathrm{~A}-43$ / CV001 [6]) plus $10 \mu \mathrm{g}$ of carrier DNA. On day 2, the cells were rinsed and refed with DMEM supplemented with $10 \%$ FBS. The cultures were refed every 5 to 6 days, and the number of transformed foci was determined 2 to 3 weeks 
later. Morphologically transformed foci were visible 7 to 10 days following transfection. Transformed foci were cloned and expanded into cell lines. The remaining cells were stained with crystal violet. The effect of wild-type p53 on transformation was determined by transfecting REFs as described above except that $1.25 \mu \mathrm{g}$ of $\mathrm{p} 53-\mathrm{XA}-2$, a derivative of a wild-type murine cDNA-genomic (introns 2 and 3) p53 clone (p53-XA [15]), a gift from G. Lozano, was included in the transfection. The p53 gene was expressed under the control of the Harvey murine sarcoma virus long terminal repeat.

Immunoprecipitation and half-life analyses. REFs and transformed cell lines were metabolically labeled for $2 \mathrm{~h}$ with $\left[{ }^{35} \mathrm{~S}\right]$ methionine EXPRESS (NEN) at $50 \mu \mathrm{Ci} / \mathrm{ml}$ in methionine-free DMEM supplemented with 5\% dialyzed FBS. At the end of the labeling period, the cells were washed with phosphate-buffered saline, scraped from the dish, pelleted at $4^{\circ} \mathrm{C}$, and stored at $-80^{\circ} \mathrm{C}$ until use. Cell pellets were lysed in lysis buffer (50 mM Tris [pH 8.0], $5 \mathrm{mM}$ EDTA, $150 \mathrm{mM}$ $\mathrm{NaCl}, 0.5 \%$ Nonidet $\mathrm{P}-40,1 \mathrm{mM}$ phenylmethylsulfonyl fluoride) for 20 to $30 \mathrm{~min}$ on ice with frequent vortexing. Equivalent amounts of trichloroacetic acid (TCA)-insoluble counts were immunoprecipitated as previously described (9). The immunoprecipitated proteins were separated on sodium dodecyl sulfate (SDS)-7.5\% polyacrylamide gels and fluorographed as previously described (9). For half-life determinations, the transformed cells were pulsed for $1 \mathrm{~h}$ with $\left[{ }^{35} \mathrm{~S}\right]$ methionine and chased for various periods of time (up to $4 \mathrm{~h}$ ) in DMEM supplemented with $10 \%$ FBS. Equivalent amounts of TCA-precipitable counts from the different time points were immunoprecipitated with PAb246 (42), and the immunoprecipitated proteins were separated on an SDS$7.5 \%$ polyacrylamide gel and fluorographed. Labeled p53 protein was solubilized from gel slices with Solvable (DuPont) and counted in a scintillation counter. One half-life was determined to be the time point at which $50 \%$ of the zero-time counts remained.

Tumorigenicity. Cell lines established from morphologically transformed foci were assayed for tumorigenicity by subcutaneous injection of $10^{6}$ cells into athymic nude mice. Three different ras-plus-mdm-2-transformed cell lines were assayed in duplicate. The transformed cells formed palpable tumors within 2 weeks.

\section{RESULTS}

Transforming activity of the $m d m-2$ gene. To characterize the transforming properties of the $m d m-2$ gene, the ability of $m d m-2$ to function as an oncogene in conjunction with an activated ras gene in primary REFs was first determined. REFs were transfected either with an activated ras gene or with an activated ras gene plus a genomic murine $m d m-2$ gene (2A-43/CV001); 7 to 10 days after transfection, multiple, dense areas of morphologically transformed cells were visible in the dishes that received ras plus $m d m-2$. No foci were observed if only the $m d m-2$ gene was transfected (7). At 14 days, the number of foci was determined; the results from these studies are presented in Table 1. Cotransfection of ras plus $m d m-2$ resulted in an average of 28 foci per experiment, demonstrating that $m d m-2$ can cooperate with an activated ras gene to transform primary cells. The number of foci observed after transfection with ras plus $m d m-2$ is, on average, less than the number of foci observed after transfection of ras plus a murine mutant p53 gene ( 28 versus 45 [7]) and, on average, 14-fold higher than the number of foci obtained after transfection with ras alone (Table 1). Low
TABLE 1. Cooperation of $m d m-2$ with activated ras to transform primary REFs

\begin{tabular}{|c|c|c|c|c|c|c|c|c|}
\hline \multirow{2}{*}{$\begin{array}{l}\text { Transforming } \\
\text { gene(s) }\end{array}$} & \multicolumn{5}{|c|}{ No. of foci } & \multirow{2}{*}{$\begin{array}{l}\text { Ratio to } \\
\text { ras } \\
\text { alone }\end{array}$} & \multirow{2}{*}{$\begin{array}{c}\text { Clon- } \\
\text { ability } \\
(\%)\end{array}$} & \multirow{2}{*}{$\begin{array}{l}\text { Tumori } \\
\text { enicity }\end{array}$} \\
\hline & $\begin{array}{c}\text { Expt } \\
1\end{array}$ & $\begin{array}{c}\text { Expt } \\
2\end{array}$ & $\begin{array}{c}\text { Expt } \\
3\end{array}$ & $\begin{array}{c}\text { Expt } \\
4\end{array}$ & Avg & & & \\
\hline $\begin{array}{l}\text { ras } \\
\operatorname{ras}+n\end{array}$ & 3 & 2 & 3 & 0 & 2 & 1.0 & $0 / 5(0)$ & $\mathrm{NA}^{a}$ \\
\hline ras $+m$ & 6 & 30 & 35 & 41 & 28 & 14.0 & $14 / 14(100)$ & $3 / 3$ \\
\hline
\end{tabular}

a NA, not applicable.

numbers of transient foci observed with ras alone have been previously noted in this assay (17) and are not able to be cloned into established lines (Table 1). To determine whether the ras-plus-mdm-2-transformed foci represented stably transformed cells, the clonability of the foci was tested. All of the 14 ras-plus-mdm-2-transformed foci were readily cloned into transformed cell lines composed of highly refractile, rapidly growing cells. Three different ras-plus$m d m$-2-transformed cell lines rapidly formed tumors in nude mice.

To examine the expression of $m d m-2$ in the transformed cell lines, primary REFs and three ras-plus- $m d m$-2-transformed cell lines were labeled with $\left[{ }^{35}\right.$ S]methionine and immunoprecipitated with rabbit preimmune serum PAb421 (a conformation-independent monoclonal antibody specific for rat, mouse, or human p53 [14]) or with a rabbit antiserum that was raised against a bacterially expressed fusion protein of the murine Mdm-2 protein that recognizes both the rat and mouse Mdm-2 proteins (31). The immunoprecipitated proteins were separated on SDS-polyacrylamide gels and subjected to autoradiography. The levels of $\mathrm{Mdm}-2$ in primary REFs are low to nondetectable; however, each of the ras-plus- $m d m$-2-transformed cell lines expresses easily detectable levels of the murine $\mathrm{Mdm}-2$ protein (Fig. 1). A complex between $\mathrm{Mdm}-2$ and the endogenous rat p53 was not detected in any of the ras-plus-mdm-2-transformed cell lines (Fig. 1). Of interest is the observation that the Mdm-2specific antiserum consistently recognizes additional unidentified cellular proteins (e.g., $60 \mathrm{kDa}$ ) in these cell lines (Fig. 1 ). Whether these are Mdm-2-associated proteins or proteins that share specific epitopes with the $\mathrm{Mdm}-2$ protein is under investigation.

Overexpression of oncogenes capable of cooperating with an activated ras gene (e.g., myc, E1A, and mutant p53) frequently results in the immortalization of primary rat cells $(19-21,24,36,37)$. The immortalizing activity of $m d m-2$ was assayed by transfecting secondary or tertiary REFs with a genomic $m d m-2$ gene in cis with the neo gene (2A-43/CV001) and determining the number of G418-resistant colonies clonable into permanent cell lines. Transfection of $m d m-2$ resulted in a significant enhancement of the plating efficiency of these cells (5- to 60-fold over four experiments) over that of REFs transfected with the neo gene alone (Table 2). Over $30 \%$ (8 of 25) of the colonies that received the $m d m-2$ gene were established into cell lines; these cell lines retained the typical fibroblast-like morphology of the parent REFs, and seven of them expressed elevated levels of the $m d m-2$ gene (7).

Effect of wild-type p53 on the transformation of REFs by $m d m-2$ plus ras. Overexpression of wild-type p53 suppresses the development of transformed foci in ras cooperation assays using mutant p53, the myc gene, or E1A from adenovirus type $5(5,8)$. To assay the effect of wild-type p53 expression on ras-plus- $m d m-2$ transformation, REFs were 


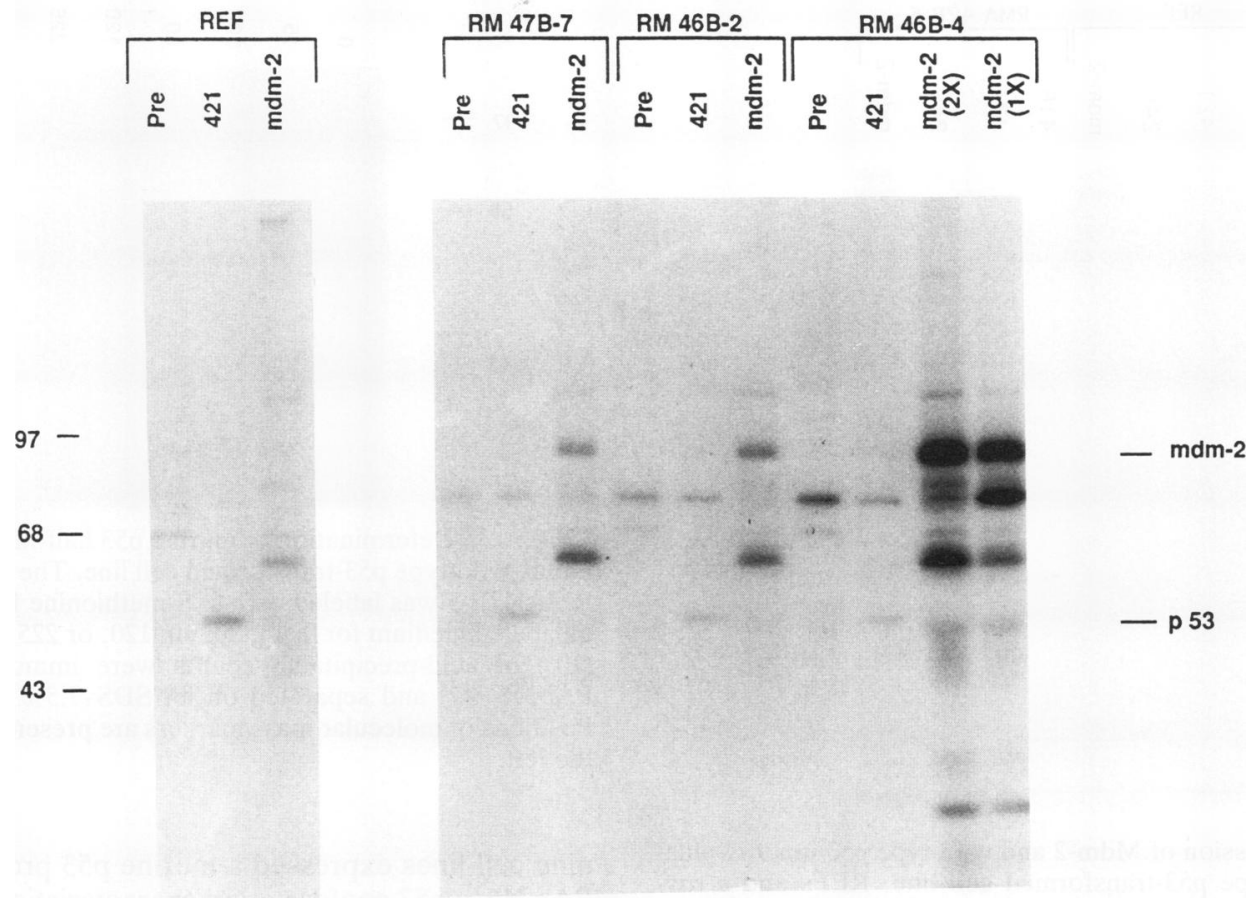

FIG. 1. Immunoprecipitation of Mdm-2 in ras-plus-mdm-2-transformed cell lines. Approximately $6.5 \times 10^{6}$ TCA-precipitable counts were immunoprecipitated from [ ${ }^{35}$ S]methionine-labeled extracts of REFs and three ras-plus-mdm-2-transformed cell lines (RM 47B-7, RM 46B-2, and RM 46B-4, respectively) with rabbit preimmune serum (Pre lanes), PAb421 (a monoclonal antibody specific for p53) (14) (lanes 421), or Mdm-2 antiserum (31) (lanes mdm-2); $2 \times$ equals twice the concentration of antibody. The proteins were separated on SDS-7.5\% polyacrylamide gels and detected by fluorography. Positions of molecular mass markers are indicated in kilodaltons on the left.

transfected with ras plus $m d m-2$ plus wild-type murine p53, and the number of foci (relative to those in REFs transfected with ras plus $m d m-2$ alone) was assayed. There was an approximate $50 \%$ reduction of transformed foci in the presence of exogenous wild-type murine p53 (Table 3). This is somewhat lower than the suppression observed previously with use of mutant p53, myc, or E1A (65 to $100 \%$ reduction) $(5,8)$. To determine whether elevated levels of p53 could be tolerated in the ras-plus-mdm-2-plus-wild-type p53-transformed cells, 17 different cell lines derived from three independent ras-plus-mdm-2-plus-wild-type p53 transfections were labeled with $\left[{ }^{35} \mathrm{~S}\right]$ methionine, and their proteins were immunoprecipitated with PAb416 (14), PAb421, PAb246 (a murine-specific monoclonal antibody that recognizes the wild-type conformation of p53 [10, 28, 42]), or the Mdm-2 antiserum. All of the cell lines expressed elevated levels of $m d m-2$, comparable to those observed in Fig. 1. Most important, 9 of 17 (1 of 6, 2 of 4, and 6 of 7 from the three respective experiments) of these cell lines expressed low levels (comparable to that of the endogenous rat p53) of

TABLE 2. Effect of $m d m-2$ on the plating efficiency of REFs

\begin{tabular}{|c|c|c|c|c|c|c|}
\hline \multirow[b]{2}{*}{$\begin{array}{l}\text { Test } \\
\text { gene }\end{array}$} & \multicolumn{5}{|c|}{ Colonies $/ 10^{6}$ cells } & \multirow[b]{2}{*}{$\begin{array}{l}\text { No. of } \\
\text { immortalizec } \\
\text { clones }\end{array}$} \\
\hline & $\underset{1}{\text { Expt }}$ & $\begin{array}{c}\text { Expt } \\
2\end{array}$ & $\underset{3}{\text { Expt }}$ & $\underset{4}{\text { Expt }}$ & $\begin{array}{l}\text { Avg } \\
\text { (no. of } \\
\text { trials) }\end{array}$ & \\
\hline CMV Bam Neo & 5 & $\mathrm{ND}^{a}$ & ND & ND & $5(1)$ & \\
\hline CV001 & ND & 8 & 42 & 6.5 & $19(3)$ & $0 / 8$ \\
\hline$m d m-2$ & 317 & 144 & 235 & 100 & 199 (4) & $8 / 25$ \\
\hline
\end{tabular}

${ }^{a} \mathrm{ND}$, not determined. a murine p53 protein (which migrates slightly faster than the rat $\mathrm{p} 53$ ). The murine $\mathrm{p} 53$ was immunoprecipitated with both PAb421 and PAb246. The cell lines expressing murine p53 were composed of highly refractile, rapidly growing cells and were indistinguishable from cell lines transformed by ras plus $m d m-2$ alone. Representative results of wild-type murine p53 expression in a ras-plus-mdm-2-plus-wild-type p53transformed cell line are shown in Fig. 2. A band comigrating with $m d m-2$ is immunoprecipitated with both PAb421 and PAb246, suggesting the ability of $m d m-2$ to bind p53 could be involved in this tolerance of p53 expression. In addition, the affinity of the murine $\mathrm{Mdm}-2$ protein for the murine p53 protein may be higher than that of murine Mdm-2 for rat p53.

Turnover of murine p53 in ras-plus-mdm-2-plus-wild-type p53-transformed cell lines. Previous studies have demonstrated that both wild-type murine and rat p53s are expressed at low levels in normal cells and that the half-life of the wild-type protein is short, typically 15 to $30 \mathrm{~min}$ (32-35). To confirm that the murine p53 expressed in the ras-plus$m d m$-2-plus-wild-type p53-transformed cell lines possesses a short half-life, pulse-chase experiments were conducted with

TABLE 3. Effect of wild-type p53 on the transformation of REFs by ras plus $m d m-2$

\begin{tabular}{|c|c|c|c|c|c|c|}
\hline \multirow[b]{2}{*}{ Test genes } & \multicolumn{5}{|c|}{ No. of foci } & \multirow{2}{*}{$\begin{array}{c}\text { Ratio to } \\
\text { ras }+ \\
m d m-2\end{array}$} \\
\hline & $\begin{array}{c}\text { Expt } \\
1\end{array}$ & $\begin{array}{c}\text { Expt } \\
2\end{array}$ & $\underset{3}{\text { Expt }}$ & $\underset{4}{\text { Expt }}$ & Avg & \\
\hline wild-type p53 & 0 & 1 & 0 & 0 & 0 & 0 \\
\hline ras $+m d m-2$ & 30 & 41 & 56 & 25 & 38 & 1.0 \\
\hline ras + mdm-2 + wild-type p53 & 15 & 31 & 21 & 15 & 20 & 0.52 \\
\hline
\end{tabular}




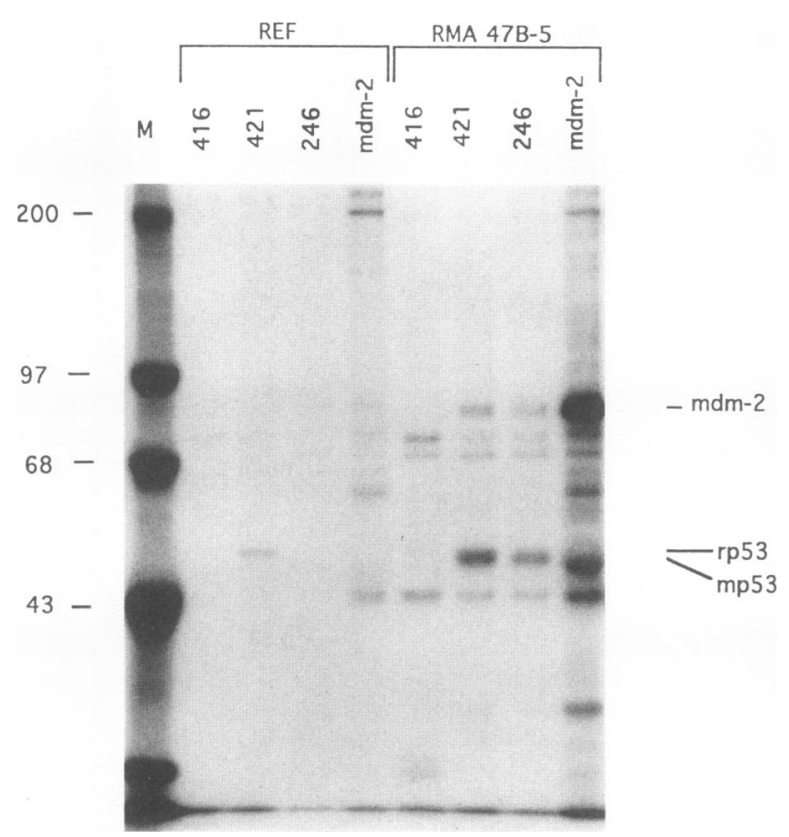

FIG. 2. Coexpression of Mdm-2 and wild-type p53 in a ras-plus$m d m$-2-plus-wild-type p53-transformed cell line. REFs and a rasplus-mdm-2-plus-wild-type p53-transformed cell line (RMA 47B-5) were labeled with $\left[{ }^{35}\right.$ S]methionine and immunoprecipitated with PAb416, a control monoclonal antibody that recognizes the SV40 large $T$ antigen (14) (lanes 416), PAb421 (lanes 421), PAb246, a conformation-dependent, murine p53-specific monoclonal antibody (42) (lanes 246), or anti-Mdm-2 antiserum (lanes mdm-2) (31). Approximately $4.0 \times 10^{6}$ and $1.2 \times 10^{7} \mathrm{TCA}$-precipitable counts were immunoprecipitated from labeled extracts of REFs and RMA 47B-5 cells, respectively. The proteins were separated on an SDS$7.5 \%$ polyacrylamide gel and fluorographed. Relative positions of the molecular size standards are shown on the left in kilodaltons. Positions of the migration of rat p53 (rp53), murine p53 (mp53), and Mdm-2 are indicated on the right.

three independent ras-plus-mdm-2-plus-wild-type p53-transformed cell lines. In each of the three cell lines, the half-life of the PAb246-reactive p53 was short (15 to $25 \mathrm{~min}$ ). Similar results were obtained when PAb421 was used (7). The half-life of Mdm-2 was also determined in two of the rasplus-mdm-2-plus-wild-type p53-transformed cell lines and was found to be short, approximately $30 \mathrm{~min}$ (7). Representative results are presented in Fig. 3 and summarized in Table 4.

The murine p53 in ras-plus-mdm-2-plus-wild-type p53transformed cell lines has wild-type properties. The murine p53 expressed in the ras-plus-mdm-2-plus-wild-type p53transformed cell lines has many properties indicative of a wild-type p53 protein (Table 4). First, the levels of murine p53 are very low in all of the nine cell lines examined, comparable to the levels of the endogenous rat p53 in REFs. Consistent with the low levels of murine p53 expression, the half-life of the murine p53 in three different cell lines was found to be short ( 15 to $25 \mathrm{~min}$ ). Previous studies have demonstrated that mutant p53 proteins are typically expressed at elevated levels in transformed cell lines $(4,9,17)$, and this is primarily the result of an increased stability of the mutant proteins $(9,13,17)$. Second, no association of the murine $\mathrm{p} 53$ protein with the cellular heat shock protein hsc70 was detected. The ability to bind to hsc70 has been associated with mutant p53 proteins $(4,9,40)$. Third, each of the

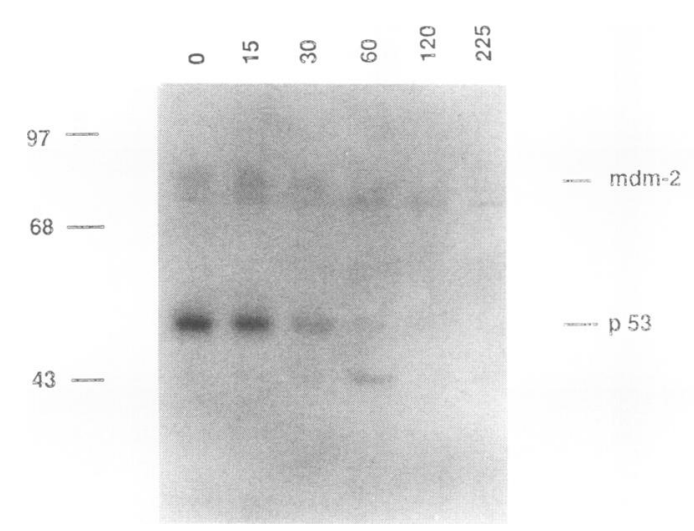

FIG. 3. Determination of murine p53 half-life in a ras-plus-mdm2-plus-wild-type p53-transformed cell line. The transformed cell line RMA 47B-5 was labeled with $\left[{ }^{35} \mathrm{~S}\right] \mathrm{methionine}$ for $1 \mathrm{~h}$ and chased in unlabeled medium for $0,15,30,60,120$, or 225 min. Equal amounts $\left(10^{7}\right)$ of acid-precipitable counts were immunoprecipitated with PAb246 (42) and separated on an SDS-7.5\% polyacrylamide gel. Positions of molecular mass markers are presented in kilodaltons on the left.

nine cell lines expressed a murine $\mathrm{p} 53$ protein reactive with PAb246, a p53 conformation characteristic of a wild-type p53 protein $(10,28)$. In addition, the proteins of three of these cell lines were analyzed by immunoprecipitation with PAb240, a monoclonal antibody that recognizes some mutant p53 proteins $(1,10)$, and none of the cell lines expressed p53 that could bind PAb240 (7). That the exogenous p53 shares these characteristics strongly argues that the transfected murine p53 genes are present in the wild-type form.

\section{DISCUSSION}

In this study, the growth-promoting properties of the Mdm-2 protein have been investigated in primary rat cells. The results presented demonstrate that, like myc, E1A, or mutant p53, the $m d m-2$ gene can immortalize primary REFs and can cooperate with an activated ras gene to transform primary REFs. Although these oncogenes ( $m d m-2, m y c$, E1A, and mutant p53) have similar transforming properties in vitro and can be classified as oncogenes capable of cooperating with ras, the mechanisms of action are not yet understood. Overexpression of these oncogenes may alter the same or different cellular pathways. The $m d m-2$ gene encodes a protein with characteristics of a transactivator (an acidic domain and a nuclear localization signal [6]) and therefore may enhance cell growth by directly altering gene expression. Although $m d m-2$ may transform by activating or repressing cellular pathways that are independent of p53 control, the fact that $m d m-2$ expression can abrogate the ability of p53 to transactivate a test gene (29) supports a model of transformation involving loss of p53 function.

TABLE 4. Characteristics of murine p53 in ras-plus-mdm-2-pluswild-type p53-transformed cell lines

\begin{tabular}{|c|c|c|c|c|c|}
\hline \multirow{2}{*}{ Cell line } & \multicolumn{3}{|c|}{ Monoclonal antibody binding } & \multirow{2}{*}{$\begin{array}{c}\text { hsc70 } \\
\text { binding }\end{array}$} & \multirow{2}{*}{$\begin{array}{l}\text { Half-life } \\
\text { (min) }\end{array}$} \\
\hline & PAb421 & PAb246 & PAb240 & & \\
\hline RMA 47B-5 & + & + & - & - & 25 \\
\hline RMA 61B-2 & + & + & - & - & 15 \\
\hline RMA 61B-5 & + & + & - & - & 15 \\
\hline
\end{tabular}


Transformation of primary rat cells by mutant p53 and ras is also thought to involve the loss of the endogenous rat wild-type p53 function (dominant loss of function) (25). Thus, $m d m-2$ and mutant p53 may transform by utilizing at least one common mechanism.

The tolerance to wild-type p53 expression in ras-plus$m d m$-2-plus-wild-type p53-transformed cells provides additional evidence that $m d m-2$ expression can overcome the negative effects of p53 on cell proliferation. This result stands in contrast to that observed upon cotransfection with ras, E1A, and wild-type p53 genes; in that case, cell lines expressing murine p53 contain only obviously mutant forms of the p53 protein (8). The fact that the number of ras-plus$m d m-2$ foci is consistently reduced following transfection with wild-type p53, coupled with the consistently low levels of wild-type p53 expression, suggests there is a selection against high levels of the wild-type protein in the transformed cell clones. Thus, although there is a tolerance to p53 expression in the presence of high levels of $\mathrm{Mdm}-2$, this is limited to only low levels of the p53 protein.

The tolerance of wild-type murine p53 expression in ras-plus-mdm-2-plus-wild-type p53-transformed cells is a phenotype unique to this cellular oncogene; expression of exogenous p53 in primary rat cells has been previously noted only with use of the SV40 large T antigen gene as a cooperating oncogene (27). Of interest is the observation that p53 binding is not necessary for this response; cell lines expressing an SV40 large $\mathrm{T}$ antigen mutant deficient for $\mathrm{p} 53$ binding also tolerated exogenous wild-type p53 expression (27). Thus, there are apparently functions provided by the large $T$ antigen (in addition to complexing p53) that are involved in the inactivation of p53-regulated pathways. By analogy, the Mdm-2 protein may also possess growth-promoting functions that can overcome the regulation of cell growth by p53 in the absence of complex formation.

Whether complex formation between Mdm-2 and p53 is necessary for part or all of the transforming activity of the Mdm-2 protein is unclear. A complex between $m d m-2$ and p53 is not detectable in the ras-plus-mdm-2-transformed cell lines, and immunoclearing experiments with Mdm-2 antiserum have confirmed that there is free p53 present in asynchronously growing cultures of these transformed cells (7). Thus, if complex formation is critical for the inactivation of p53, only a small subset of the p53 molecules in the cell are present in an active form. Alternatively, the complex may transiently form only at distinct control point(s) in the cell cycle. It is also possible that the ratio of $m d m-2$ to p53 is important for transformation; overexpression of $m d m-2$ may directly promote cell growth by raising the level of free, presumably active, $m d m-2$. Experiments are in progress to distinguish among these possibilities.

The results presented in this report form the basis for a prediction about the inactivation of p53 in human tumors. If $m d m-2$ can act as an oncogene, there should exist tumors that have amplified the $m d m-2$ gene. Furthermore, if the transforming activity of $m d m-2$ results, at least in part, from the ability of $m d m-2$ to abrogate p53 activity, these tumors should also express wild-type p53. Recent studies from the Vogelstein laboratory have demonstrated the amplification of the $m d m-2$ gene in liposarcomas, malignant fibrous histiocytomas, and osteosarcomas, and five tumors with elevated $m d m-2$ levels possessed wild-type p53 (30). Thus, the $m d m-2$ gene product is an oncogene that may act, at least in part, through the inactivation of the p53 tumor suppressor gene product. Experiments designed to determine the mecha- nism(s) by which $m d m-2$ acts to overcome the regulation of cell growth by $\mathrm{p} 53$ are in progress.

\section{ACKNOWLEDGMENTS}

I thank A. K. Teresky for excellent technical assistance and K. James for assistance with the manuscript. I am grateful to A. J. Levine for the generous gift of the Mdm-2 antiserum.

The work was supported by Public Health Service grant R01 CA55036 from the National Cancer Institute. I am a Special Fellow of the Leukemia Society.

\section{REFERENCES}

1. Bartek, J., R. Iggo, J. Gannon, and D. P. Lane. 1990. Genetic and immunochemical analysis of mutant p53 in human breast cancer cell lines. Oncogene 5:893-899.

2. Choo, K. H., G. Filby, S. Greco, Y.-F. Lau, and Y. W. Kan. 1986. Cosmid vectors for high efficiency DNA-mediated transformation and gene amplification in mammalian cells: studies with the human growth hormone gene. Gene 46:277-286.

3. Crook, T., J. A. Tidy, and K. H. Vousden. 1991. Degradation of p53 can be targeted by HPV E6 sequences distinct from those required for p53 binding and trans-activation. Cell 67:547-556.

4. Eliyahu, D., N. Goldfinger, O. Pinhasi-Kimhi, G. Shaulsky, Y. Skurnik, N. Arai, V. Rotter, and M. Oren. 1988. Meth A fibrosarcoma cells express two transforming mutant p53 species. Oncogene 3:313-321.

5. Eliyahu, D., D. Michalovitz, S. Eliyahu, O. Pinhasi-Kimhi, and M. Oren. 1989. Wild-type p53 can inhibit oncogene-mediated focus formation. Proc. Natl. Acad. Sci. USA 86:8763-8767.

6. Fakharzadeh, S. S., S. P. Trusko, and D. L. George. 1991. Tumorigenic potential associated with enhanced expression of a gene that is amplified in a mouse tumor cell line. EMBO J. 10:1565-1569.

7. Finlay, C. A. Unpublished data.

8. Finlay, C. A., P. W. Hinds, and A. J. Levine. 1989. The p53 proto-oncogene can act as a suppressor of transformation. Cell 57:1083-1093.

9. Finlay, C. A., P. W. Hinds, T.-H. Tan, D. Eliyahu, M. Oren, and A. J. Levine. 1988. Activating mutations for transformation by p53 produce a gene product that forms an hsc70-p53 complex with an altered half-life. Mol. Cell. Biol. 8:531-539.

10. Gannon, J. V., R. Greaves, R. Iggo, and D. P. Lane. 1990. Activating mutations in p53 produce common conformational effects: a monoclonal antibody specific for the mutant form. EMBO J. 9:1595-1602.

11. Goldfarb, M., K. Shimizu, M. Perucho, and M. Wigler. 1982. Isolation and preliminary characterization of a human transforming gene from T24 bladder carcinoma cells. Nature (London) 296:404-409.

12. Graham, F. L., and A. J. van der Eb. 1973. A new technique for the assay of infectivity of human adenovirus 5 DNA. Virology 52:456-467.

13. Halevy, O., D. Michalovitz, and M. Oren. 1990. Different tumor-derived p53 mutants exhibit distinct biological activities. Science 250:113-116.

14. Harlow, E., L. V. Crawford, D. C. Pim, and N. M. Williamson. 1981. Monoclonal antibodies specific for simian virus 40 tumor antigen. J. Virol. 39:861-869.

15. Hinds, P., C. Finlay, and A. J. Levine. 1989. Mutation is required to activate the $\mathrm{p} 53$ gene for cooperation with the ras oncogene and transformation. J. Virol. 63:739-746.

16. Hinds, P. W., C. A. Finlay, A. B. Frey, and A. J. Levine. 1987. Immunological evidence for the association of $\mathrm{p} 53$ with a heat shock protein, hsc70, in p53-plus-ras-transformed cell lines. Mol. Cell. Biol. 7:2863-2869.

17. Hinds, P. W., C. A. Finlay, R. S. Quartin, S. J. Baker, E. R. Fearon, B. Vogelstein, and A. J. Levine. 1990. Mutant p53 cDNAs from human colorectal carcinomas can cooperate with ras in transformation of primary rat cells: a comparison of the "hot spot" mutant phenotypes. Cell Growth Differ. 1:571-580.

18. Hollstein, M., D. Sidransky, B. Vogelstein, and C. C. Harris. 1991. p53 mutations in human cancers. Science 253:49-53. 
19. Houweling, A., P. J. van der Elsen, and A. J. van der Eb. 1980. Partial transformation of primary rat cells by the leftmost $4.5 \%$ fragment of adenovirus 5 DNA. Virology 105:537-550.

20. Jenkins, J. R., K. Rudge, and G. A. Currie. 1984. Cellular immortalization by a cDNA clone encoding the transformationassociated phosphoprotein p53. Nature (London) 312:651-654.

21. Land, H., A. C. Chen, J. P. Morgenstern, L. F. Parada, and R. A. Weinberg. 1986. Behavior of myc and ras oncogenes in transformation of rat embryo fibroblasts. Mol. Cell. Biol. 6:1917-1925.

22. Lane, D. P., and L. V. Crawford. 1979. T antigen is bound to a host protein in SV40-transformed cells. Nature (London) 278: 261-263.

23. Lechner, M. S., D. H. Mack, A. B. Finicle, T. Crook, K. H. Vousden, and L. A. Laimins. 1992. Human papillomavirus E6 proteins bind $\mathrm{p} 53$ in vivo and abrogate $\mathrm{p} 53$-mediated repression of transcription. EMBO J. 11:3045-3052.

24. Levine, A. J., C. A. Finlay, and P. W. Hinds. 1989. The p53 proto-oncogene and its product, p. 21-37. In L. P. Villarreal (ed.), Common mechanisms of transformation by small DNA tumor viruses. American Society for Microbiology, Washington, D.C.

25. Levine, A. J., J. Momand, and C. A. Finlay. 1991. The p53 tumor suppressor gene. Nature (London) 351:453-456.

26. Linzer, D. I. H., and A. J. Levine. 1979. Characterization of a $54 \mathrm{~K}$ dalton cellular SV40 tumor antigen in SV40 transformed cells. Cell 17:43-52.

27. Michael-Michalovitz, D., F. Yehiely, E. Gottlieb, and M. Oren. 1991. Simian virus 40 can overcome the antiproliferative effect of wild-type p53 in the absence of stable large T-antigen-p53 binding. J. Virol. 65:4160-4168.

28. Milner, J., E. A. Medcalf, and A. C. Cook. 1991. Tumor suppressor p53: analysis of wild-type and mutant p53 complexes. Mol. Cell. Biol. 11:12-19.

29. Momand, J., G. P. Zambetti, D. C. Olson, D. George, and A. J. Levine. 1992. The mdm-2 oncogene product forms a complex with the p53 protein and inhibits p53 mediated transactivation. Cell 69:1237-1245.

30. Oliner, J. D., K. W. Kinzler, P. S. Meltzer, D. George, and B. Vogelstein. 1992. Amplification of a gene encoding a p53-associated protein in human sarcomas. Nature (London) 358:80-83.
31. Olson, D., J. Momand, and A. J. Levine. Unpublished data.

32. Oren, M., W. Maltzman, and A. J. Levine. 1981. Post-translational regulation of the $54 \mathrm{~K}$ cellular tumor antigen in normal and transformed cells. Mol. Cell. Biol. 1:101-110.

33. Reich, N. C., M. Oren, and A. J. Levine. 1983. Two distinct mechanisms regulate the levels of a cellular tumor antigen, p53. Mol. Cell. Biol. 3:2143-2150.

34. Reihsaus, E., M. Kohler, S. Kraiss, M. Oren, and M. Montenarh. 1990. Regulation of the level of the oncoprotein p53 in non-transformed and transformed cells. Oncogene 5:137-145.

35. Rogel, A., M. Popliker, C. G. Webb, and M. Oren. 1985. p53 cellular tumor antigen: analysis of mRNA levels in normal adult tissues, embryos, and tumors. Mol. Cell. Biol. 5:2851-2855.

36. Rovinski, B., and S. Benchimol. 1988. Immortalization of rat embryo fibroblasts by the cellular p53 oncogene. Oncogene $2: 445-452$.

37. Ruley, H. E., J. F. Moomaw, and K. Maruyama. 1984. Avian myelocytomatosis virus myc and adenovirus early region $1 \mathrm{~A}$ promote the in vitro establishment of cultures primary cells, $\mathrm{p}$. 481-486. In G. F. Vande Woude, A. J. Levine, W. C. Topp, and J. D. Watson (ed.), Cancer Cells 2. Cold Spring Harbor Laboratory, Cold Spring Harbor, N.Y.

38. Sarnow, P., Y. S. Ho, J. Williams, and A. J. Levine. 1982. Adenovirus E1B-58Kd tumor antigen and SV40 large tumor antigen are physically associated with the same $54 \mathrm{Kd}$ cellular protein in transformed cells. Cell 28:387-394.

39. Scheffiner, M., B. A. Werness, J. M. Huibregtse, A. J. Levine, and P. M. Howley. 1990. The E6 oncoprotein encoded by human papillomavirus 16 or 18 promotes the degradation of p53. Cell 63:1129-1136.

40. Stürzbecher, H.-W., P. Chumakov, W. J. Welch, and J. R. Jenkins. 1987. Mutant p53 proteins bind hsp $72 / 73$ cellular heat shock-related proteins in SV40-transformed monkey cells. Oncogene 1:201-211.

41. Werness, B. A., A. J. Levine, and P. M. Howley. 1990. Association of human papillomavirus types 16 and 18 E6 proteins with p53. Science 248:76-79.

42. Yewdell, J., J. V. Gannon, and D. P. Lane. 1986. Monoclonal antibody analysis of p53 expression in normal and transformed cells. J. Virol. 59:444-452. 